\title{
MRC follows NIH on patents
}

\section{London}

BritaIN's Medical Research Council (MRC) has decided to follow the US National Institutes of Health (NIH) in filing for patents to cover the complementary DNA (cDNA) fragments sequenced by its genome researchers. But the move, announced last week by Alan Howarth, UK science and higher education minister, is being taken reluctantly.

Britain would like the other countries with major cDNA sequencing efforts to agree by international treaty not to file for patents on genome sequences of unknown utility. But in the absence of such an agreement, MRC says it has no choice but to file for patents itself.

MRC officials last summer strongly criticised Craig Venter, a researcher at $\mathrm{NIH}$, after he filed a patent covering more than $300 \mathrm{cDNA}$ fragments. They argued that an attempt to claim patent rights for genes of unknown function, on the basis of incomplete sequences, ran counter to the spirit of international collaboration at the heart of the Human Genome Project (see Nature 353, 785; 1991). But the MRC has now taken the same route, now that Venter's original application has been followed by a second one, this time covering 2,375 genes (see Nature 355, 665; 1992).

The first MRC patent application will be filed within the next two weeks, and will cover more than 1,000 cDNA sequences (about half of the sequences identified by the MRC team). The main motivation is to ensure that Britain will not be at a competitive disadvantage if the NIH patents are granted.

MRC secretary Dai Rees says that the MRC intends to match the NIH move-formove, filing its initial application in the United States, rather than with the European or British patent offices. This should mean that the NIH and MRC applications will stand or fall together. Dai George, from the Association of the British Pharmaceutical Industry, also believes that the US Patent Office is more likely than its European counterparts to grant patents for cDNA sequences. US patent examiners "take a broader view of what is patentable," he says.

British drug companies are reluctant to comment on the patent applications until they have studied their wording. Patent agents hired by the MRC are still working on the British application, and although Venter's original application has now been released by the NIH, British companies have not yet examined it.

The MRC application puts the council at odds with the Royal Society, which denounced cDNA patenting in a statement late last month. But Anne McLaren, the Royal Society's foreign secretary, says she accepts that the MRC had little choice but to follow the NIH's lead if it hopes to protect the UK government's commercial interests.

The British move is expected also to focus attention on the other countries with major cDNA sequencing efforts. French research minister Hubert Curien has outlined his opposition to cDNA patenting in a recent letter to Science $(254,1710 ; 1991)$. A generalized system of patenting the human genome would be "ethically unacceptable", Curien wrote. "A patent should not be granted for something that is part of our universal heritage."

Japan, the other country with a sizeable cDNA sequencing effort, has yet to reveal its position. But if Japanese officials also choose the patenting route, the French research ministry would face formidable pressure to abandon the moral high ground. French companies are unlikely to be happy if forced to negotiate licences with foreign agencies to exploit cDNA sequence data, when their own government has been one of the most generous supporters of cDNA sequencing.

Nevertheless, Curien will be an important ally as the British government attempts to secure an international agreement to waive any cDNA patents that may be awarded. Howarth was expected to raise the issue this week, at a meeting in Paris of science ministers and advisers from the industrialized nations that make up the Organization for Economic Cooperation and Development. But with US officials showing strong support for the NIH patent applications, prospects for an agreement in the foreseeable future seem dim.

Whatever its long-term commercial implications, the MRC's decision to file for cDNA patents means that researchers should soon get access to the British cDNA sequence data. The MRC had intended to open its cDNA sequence database last November, but these plans were shelved after Venter's surprise patent application. Once a patent has been filed safely, however, the MRC will be able to release data for the sequences covered by the application without undermining its intellectual property rights.

Rees says that the MRC is reviewing its controversial scheme to charge commercial users a fee to subscribe to its cDNA database (see Nature 354, 96; 1991). He maintains that the plan was widely misunderstood, and was designed merely to get industry to contribute towards the cost of the database, rather than being an attempt to profit from genome research.

For their part, industry sources seem unconcerned. "We'd rather not pay," says one senior British pharmaceutical industry scientist. "But in this business, pragmatism rules."

\section{Instant initiative}

Eager to show his commitment to reviving a sluggish US economy as he campaigns for reelection, President George Bush last week told his science adviser, D. Allan Bromley, to begin a new research initiative on advanced manufacturing.

There have been five such initiatives since Bush took office in 1989. Each was announced as part of the president's annual budget request to Congress in January, and unveiled only after agency officials compiled a lengthy inventory of existing federal programmes and detailed plans of how the government should spend its money. In contrast, the manufacturing initiative was approved at a meeting on 2 March of an inter-agency coordinating council and announced three days later at a press conference, with no accompanying list of current projects and no description of research priorities. The White House has not even chosen a chairman for the panel that will oversee the initiative, according to Bromley.

J.D.M.

\section{No SSC for India}

THE new Indian budget (see page 97) contains no money to continue its support for the US Superconducting Super Collider (SSC). India has pledged $\mathbf{\$ 5 0}$ million to the $\$ 8,500$ million proton-proton accelerator being built in Texas - the first and so far only foreign contribution - and research teams in India have been hard at work for nearly three years designing prototypes for various parts of the gigantic machine.

Roy Schwitters, director of the SSC laboratory, says he "knows nothing" of any change in policy, pointing out that the head of the Atomic Energy Department in India visited the laboratory a few weeks ago to discuss ways to expand collaborative efforts. Indian officials have declined to say whether last week's budget reflects a temporary omission or a fundamental change in policy. J.D.M.

\section{Activists burn lab}

ANIMAL activists ransacked and burned the offices of a toxicology researcher at Michigan State University late last month, causing between $\$ 50,000$ and $\$ 100,000$ in physical damage and destroying years of research data. In the early-morning raid, the activists targeted both Richard Aulerich, a scientist investigating the effect of common environmental contaminants on mink, and a mink research farm, where the animals were housed. Aulerich's data and other files were opened and burned in the fire. People for the Ethical Treatment of Animals released a statement on behalf of the underground group Animal Liberation Front (ALF) that credited the raid to ALF members and described it as the first action by the group in Michigan. 